whether limited monarchy, aristocracy, or democracy, in much the same dissatisfied and despairing tone in which the Preacher of old did. But he concludes his book with drawing comfort from a source which his predecessor of old pronounced impossible. He says :-

"There is yet one branch of human progress which we may contemplate with umixed satisfaction, and that is, the progress of science, both in its discoveries and its adaptations to the convenience and civilisation of mankind. It may be hoped that the acquisitions of science may become an enduring benefit to the world, not to be again obliterated and lost amid the political convulsions to which society may be subjected.

"To this progress the scientific men of every country may contribute, whetber they live under a despotism or under a constitutional government. The pursuit of truth for its own sake is the noblest occupation of the human mind, and from this pursuit it seems proboble that mankind will reap the richest reward."

A fairer comment fr ma mo:e qualified and disinterested writer was never made upon the motto of this journal-

$$
\text { "To the solid ground }
$$

Of Nature trusts the mind which builds for aye."

W. $O$.

\section{Scientific Jokes}

You can hardly expect all your readers to see through the jokes at p. 337 of your last number. I instance only two out of many.

"The energy of heat is made up of heat and temperature" ! This may set some earnest but i nnorant students to find how Joule's Equivalent depends on temperature : and it would be well to warn them.

"Profs. Ayrton and Perry have developed a theory of terrestrial magnetism . . . which coincides well with facts." Here the reader should have been told that Rowland has proved that, according to this theory, the moon would have been repelled into the profundity of space, and the greater part of the earth's surface, including its atmosphere, torn off by the enormous electric forces involved.

G. H.

\section{Stags' Horns}

CONCERNING the disappearance of cast horns, the theory that stags retire to secluded spots, about the time for shedding their horns, mentioned by B. W. Barton in NATuRE, vol, xxi.p. 325, may be perfectly correct where the animals have woods to go to, but this opinion cannot hold good with the thousands of reindeer that frequent the barren lands of the north-east part of America; yet it is rare to find on these "barrens" the shed horn of either buck or doe, although the latter drop their horns in May or June, when at or on their way to their far north summer quarters.

As far as I have observed, the new horns of the male reindeer (in the wild state) do not begin to grow until weeks after the old ones have dropped off, and there is no danger of one stag "disturbing" another, when all have their horns in the tender velvety stage; in fact, no animals can be less pugnacious than these fine creatures are during eight months of the year.

2, Addison Gardens, South Kensington, Feb. 7 J. RAE

Apropos of the question of stags' horns, I have just come upon the following in Miss Bird's "Life in the Rocky Mountains."

Describing the so-called "Parks" of the Rocky Mountains as "bigh-lying valleys large and small, at heights varying from 6,000 to II, cos feet," she says, "Parks innumerable are scattered throughout the mountains. . . They always lie far within the Foot Hills. . . Hundreds can only be reached by riding in the bed of a stream, or by scrambling up some narrow cañon till it debouches on the fairy-like stretch above. These parks are the feeding-grounds of innumerable wild animals, and some, like one three miles off, seem chosen for the process of antlercasting, the grass being covered for at least a square mi'e with the magnificent branching horns of the elk." P. I22. B. W. S.

\section{"Song of the Screw"}

Frof. TAIT has inadvertently attributed to the late lamented Prof. Clerk Maxwell (NATURE, vol, xxi. p, 32I) an effusion of mine consisting of a synopsis of Dr. Ball's Treatise on Screws, which appeared in NATURE, vol, xiv. p. 30 , under the above title.
As a very humble poet, the occurrence of such a mistake has satisfied my highest ambition; and I feel like a second Chatterton. J. D. EVERETT

\section{The Post Office and the Telephone}

PRAY allow me to correct an important misprint which has occurred in the last paragraph of the abstract of my address which you were good enough to insert in your last number. I said that the Post Office did not wish to restrict or in any way to interfere with the use of the telephone; our only object was to prevent the establishment of a particular branch of Post Office telegraph business without, not with, its licence or consent. General Post Office, February 9

W. H. PREECE

\section{KARL VON SEEBACH}

CEOLOGISTS will learn with universal regret of the death, after a painful illness, of the distinguished Professor of Geology at Göttingen, Karl von Seebach. Although Prof. von Seebach was still a young man at the time of his death, he had already made his mark in science, and his career promised a distinguished future. Von Seebach's earliest studies were devoted to stratigraphical geology and palæontology, and he devoted much time to the preparation of a geological map of the kingdom of Hanover, and to his earnest labours much of the excellence of this map is due. The result of Prof. von Seebach's studies of the stratified rocks of Hanover are embodied in a number of separate memoirs and in his well known treatise "Die Hannoverischer Jura."

During his later years Karl von Seebach's studies were devoted to wider questions, and the investigation of volcanic phenomena occupied his attention. He visited the island of Santorin and wrote an important work on the eruption of 1866 . He also published several interesting memoirs on the volcanoes of Central America, a district which he visited in 1865 . Geological science has sustained a heavy loss by his early death.

\section{ARTHUR JULES MORIN}

THE serious illness of General Morin to which we alluded in our last number, was followed by his death at Paris on Saturday, February 7 , in his eighty-fifth year. Arthur Jules Morin was born at Paris, October 17, 1795. He entered at an early age the famous Ecole Polytechnique, but was summoned from his studies during the fatal campaign of 1814 to assist in the defence of Paris, and rendered good service in the brigade of artillery. At the conclusion of peace he devoted four years to practical studies in military engineering at the École d'Application of Metz, and entered the army as lieutenant in a pontoon regiment. His military career was marked by a rapid and regular promotion through the different grades, terminating in his appointment as an Artillery General of Division in 1855 .

General Morin's reputation rests however chiefly on his achievements in the peaceful departments of physical research, as well as on unusual executive abilities in the same connection. As an investigator his attention was directed almost entirely to the solution of problems in mechanics. In a remarkable series of memoirs presented to the Academy at Paris, during the years I833-1835, Morin gave the results of exhaustive experiments on friction, and established the three general laws of this part of mechanics, viz. :-Friction is proportional to the pressure exerted by a body on the supporting surface depends on the nature and smoothness of the surfaces in contact, but not on their superficies; and is independent of the rapidity of the motion. Equally well-known is his ingenious apparatus for determining the laws of falling bodies, in which a pencil attached to a falling -weight, describes a curve on a perpendicular cylinder, rotating alongside the path of the descending body. The parabolic curve obtained by this simple but exact contrivance, 
demonstrates most perfectly the proportionality of the spaces described to the squares of the times employed in their description. In this connection should also be mentioned his valuable inventions of the dynameter of rotation, and the dynametric crank. In 1853-1854, Morin communicated a most valuable series of experimental results on the resistance of building materials, by means of which he established several important principles of practical application in the solution of architectural problems. Among less prominent researches, mention should be made of those on gun-cotton (I 849), on the production of carbon monoxide in rooms heated by iron stoves (1869), and on the preservation of flour (1870).

As an author, General Morin is best known by his two works "Leçons de Mécanique pratique" and "Résistance des Matériaux" ( 1853 ) ; as well as by able reports on various technical and military inventions referred to him by the French War Department and the Academy of Sciences.

General Morin's executive abilities have long been appreciated and utilised at Paris. After occupying for some time the chair of mechanics at the Conservatoire des Arts et Métiers, he was appointed director of this jmportant establishment in 1849 . Under the thirty years of his régime the efficiency and influence of the Conservatoire has been vastly increased and strengthened, until it has become the chief auxiliary in elevating and educating the artisan classes of the French capital. In I 855, General Morin occupied the difficult and trying position of president of the commission for the first Universal Exhibition held at Paris. In 1862 he was elected president of the French Society of Civil Engineers. Since 1858 , he has been a grand officer in the Legion of Honour. He was elected a member of the French Academy of Sciences in 1843, as successor to Coriolis in the section of mechanics, and has always maintained an influential position in the actions of that body.

T. H. N.

\section{PRE-HISTORIC MAN IN JAPAN 1}

$M$ R. MORSE seems to claim for the shell-mounds 1 lately investigated by him at Omori (wrongly spelled Omori throughout his monograph), a small village a few miles from Yedo, an antiquity as high as that of the Danish kitchen-middens. I cannot help thinking the conclusion a hasty one, or, at least, not warranted by the facts set forth in the monograph in question. The shellmounds are therein described as situate about half a mile from the shore, and the principal heap is stated to be some ninety metres in length by about four metres in breadth. It is now, I believe, completely swept away.

These mounds consist for the most part of shells, little, if at all, distinguishable from what are still to be found in abundance along the shores of the Gulf of Yedo, mixed with fragments of pottery, implements of stone and horn, clay ornaments and "tablets," together with bones of the monkey, bear, deer, dog, wild boar, and of man, the human bones or their fragments being nearly as numerous as those of the remaining mammals. Of the eighteen lithographed plates with which the monograph is embellished, fifteen are devoted to the delineation of fragments of pottery, and one cannot but regret that some of this space was not used for drawings of the bones and shells, especially of such of the latter as are stated to belong to extinct species. A figure, too, of the right lower jaw of the "large baboon-like ape" alleged to be "certainly unlike anything found in Japan to day," and supposed to belong to a species of cynopithicus (sic), would have been a most welcome addition. The fragments of pottery, of which drawings are given, do not 1 "Memoirs of the Science Department, University of Tokio, Japan," vol. i. Fart r. "Shell-mounds of Omori." By E. S. Morse, Prufessor of
Zoology, University of Tokio, Japan. Published by the University of Zoology, University of Tokio, Japan. Published by
Tokio, Japan. Nisshusha Print:ng Office, 2539 ( 1879 ). tell us much. A coarse ware, with not very dissimilar ornamentation, is not hard to meet with in country villages, and inferior specimens of the well-known "banko" faience are commonly adorned with lines, strokes, dots, and "hatchings," that bear no little resem blance to those delineated in Mr. Morse's figures. The drawings and descriptions of the stone implements do not help us towards pronouncing upon their antiquity. The distance of the shell-mounds from the shore is in no way remarkable, and does not of itself prove any change of level since the period of their accumulation. Clear evidence, however, but of a very different nature, may be found in the neighbourhood of Yedo and Yokohama, of alternate elevations and depressions of the land, and it is probable that at the present day the waters of the Gulf of Yedo are slowly receding. Remains and traces of shellheaps of quite modern date are common enough in the provinces of Musashi and Sagami, and doubtless elsewhere also, at a considerable distance from the shore, even far inland. I am inclined to believe that the dog is not indigenous to Japan, but has been introduced from China. The Japanese name "inu," indeed, seems to be connected with the Chinese word for dog "Kiuen" (cf. Greek xú $\omega \nu$, Latin canis). ${ }^{1}$ Lastly, the "adzuma," or eastern region of the main island was probably peopled shiefly by an Aino race, up to the fourteenth or fifteenth centuries. Yedo was not founded before the close of the sixteenth century. Legend, indeed, tells us that Nikkò was "opened" by the Buddhist saint, Shôdô shônin, in the eighth century, and that shrines were erected there towards the middle of the ninth century; but it seems probable that up to at least as late as the fourteenth century the country east of the Hakoné Pass was principally inhabited by an aboriginal race.

Upon these grounds, and in the absence of materials for instituting a comparison between the mound-shells and recent forms, I should hesitate to assign a higher antiquity to the Ômori heaps than the thirteenth or fourteenth century, and it seems to me more probable that they were the work of an Aino race than of contemporaries of the builders of the Danish middens. The question of cannibalism I have not space to discuss. We know so little about the Ainos and their customs that it is impossible to say whether these might or might not explain the occurrence of human bones in the heaps without loading the memory of a docile and gentle folk with the odious charge of anthropophagism.

Some of Mr. Morse's statements require considerable modification. The chronicles of Japan do not run back for I,500 years, or for anything like that period. The legends run back, it is true, much farther, some millions of years indeed, but the oldest Japanese book extant, the "Kojiki," a mere collection of myths, was compiled in the eightl century of our era. The art of writing was introduced from China, hardly earlier than the sixth century, and the annals of Japan up to quite recently presented such a mixture of fact and fable that they are of but small historical value. I must add that the statement in the preface that "there is no other country in the world where so great a number of gentlemen interested in archæology can be found as in Japan," is to me a most surprising one.

The lithographs are excellent, and the paper and typography are good ; but surely Mr. Morse will hardly please his Japanese friends by patting them upon the back, as if they were clever savages, because they have performed the not very extraordinary feat of making paper with European machinery, and under European superintend. ence or instruction, and the still more insignificant one, for some ten or fifteen years familiar to the native compositors of a dozen printing offices in Yokohama, of printing a few score pages of English with tolerable clearness and accuracy. FREDK. V. DICKINS 